\title{
The influence of adverse events on the quality of nursing care and patients' safety
}

\section{Wpływ identyfikacji zdarzeń niepożądanych na jakość opieki pielęgniarskiej i bezpieczeństwo chorych}

\author{
Maria Mika', Grażyna Nowak-Starz ${ }^{2}$, Ireneusz Kotela ${ }^{3}$ \\ ${ }^{1}$ Department of Nursing, The Institute of Health Science, State Higher Vocational School, Tarnow, Poland \\ Head of the Department: Małgorzata Kołpa PhD \\ ${ }^{2}$ Department of Developmental Age Research, Institute of Public Health, Faculty of Health Sciences, Jan Kochanowski University, \\ Kielce, Poland \\ Head of the Department: Prof. JKU Grażyna Nowak-Starz MD, PhD \\ ${ }^{3}$ Department of Rehabilitation in Disease of the Locomotor, Institute of Physiotherapy, Faculty of Sciences, Jan Kochanowski University, \\ Kielce, Poland \\ Head of the Department: Prof. Ireneusz Kotela MD, PhD
}

Key words: adverse events, quality, patient safety, nurse.

Słowa kluczowe: zdarzenia niepożądane, jakość, bezpieczeństwo pacjenta, pielęgniarka.

\begin{abstract}
Introduction: High quality of medical services is essential to proper healthcare functioning and to achieve aims. High quality of nursing care should have the same characteristics as the whole healthcare system. Although current healthcare systems focus on best quality medical services, the number of adverse events is increasing. It sometimes happens that a patient suffers injuries not due to his/her illness, but because of poorly organised healthcare.

Aim of the research: To assess the influence of adverse events and their identification on nursing care quality and to analyse the correlation between patient safety and adverse events identification and reporting.

Material and methods: The research was conducted in hospital wards that have and do not have a Certificate of Quality Management System. In the research, the Hospital Survey on Patient Culture prepared by the Agency for Healthcare Research and Quality was used as well as the author's own survey.

Results: In the survey, nurses' activities were evaluated in the context of adverse events identification. As the most common undesirable events, the following were considered: discrepancy connected with organisation and administration (35\%), medical equipment (24\%), hospital infections (23\%), medication administration (22\%), doctor's (20\%) and nurse's (19\%) activity, and blood and blood related specimen transfusion (10\%). However, these areas were not disastrous.

Conclusions: It has been stated that nurses, for fear of disciplinary consequences, are more unwilling to report such events. Therefore, it is essential to introduce legal regulations.
\end{abstract}

\section{Streszczenie}

Wprowadzenie: Zapewnienie wysokiej jakości świadczeń zdrowotnych jest niezbędnym warunkiem osiągania celów i funkcjonowania systemu opieki zdrowotnej. Opieka pielęgniarska wysokiej jakości powinna charakteryzować się podobnymi cechami jak cały system opieki zdrowotnej. Współczesne systemy ochrony zdrowia dużą wagę przykładają do zapewnienia jak najwyższej jakości usług zdrowotnych, mimo to wzrasta liczba zdarzeń niepożądanych, kiedy to pacjent doznaje uszczerbku na zdrowiu niezwiązanego z chorobą, ale z wadliwie zorganizowaną opieką zdrowotną.

Cel pracy: Określenie wpływu zdarzeń niepożądanych i ich identyfikacji na jakość opieki pielęgniarskiej oraz analiza związku pomiędzy bezpieczeństwem pacjenta a identyfikacją i zgłaszaniem zdarzeń niepożądanych.

Materiał i metody: Badaniami objęta została grupa 364 osób - pielęgniarek i pielęgniarzy pracujących na oddziałach szpitalnych, którzy posiadają Certyfikaty Systemu Zarządzania Jakością lub ich nie posiadają. W badaniach wykorzystano Sondaż szpitalny o bezpieczeństwie pacjenta (Hospital Survey on Patient Culture) oraz ankietę własnej konstrukcji.

Wyniki: Ocenie poddano wyodrębnione czynności wykonywane przez pielęgniarki w kontekście identyfikowania zdarzeń niepożądanych i ich wpływu na jakość opieki nad chorym. W analizach uwzględniono obszary, w których najczęściej identyfikowane były niezgodności związane z organizacją i administracją (35\%), ze sprzętem medycznym (24\%), zakażeniami szpitalnymi (23\%), podaniem leku (22\%), czynnościami lekarskimi (20\%), czynnościami pielęgniarskimi (19\%), z przetacza- 
niem krwi i preparatów krwiopochodnych (10\%). Należy zaznaczyć, że obszary, w których badane pielęgniarki zidentyfikowały zdarzenia niepożądane, nie są katastrofalne.

Wnioski: Stwierdzono częstsze przypadki niezgłaszania zdarzeń niepożądanych przez pielęgniarki uwarunkowane m.in. obawami przed konsekwencjami służbowymi. Wskazane jest wprowadzenie uregulowań prawnych dotyczących opracowania stosownego narzędzia do zgłaszania zdarzeń niepożądanych.

\section{Introduction}

The main principle of current nursing, which is based on the nursing process in accordance with the nursing theories in force, is the care of a man/woman and his/her health [1-4].

Providing patients with highest quality professional service, adjusted to their needs and expectations, should constitute the main issue in the process of healthcare improvement. Quality in nursing care is one of many crucial elements of healthcare. It concerns the direct interaction between the patient and the nurse. Such care constitutes one of the widest areas of medical services, performed in the closest and most direct contact with a patient.

Currently, quality in healthcare has become a must and constitutes one of the most important issues for healthcare managing institutions and for patients using medical services. It is particularly crucial to take into consideration patients' expectations concerning the quality of the medical services they receive.

The patient should be the most important for the service provider. Medical services that are perceived as high quality should come up to patients' expectations [5]. ISO accreditation and management systems constitute professional assessment of the quality of the services provided to the patients in healthcare unities. At present, more and more healthcare institutions are taking action in order to implement quality management tools.

Nowadays, the priority for the ongoing changes in the Polish healthcare system is providing high quality medical services, in the form of patients' rights - "the Patient has a right to medical services that are provided with diligence by the entity providing services in the conditions established by separate specialist and sanitary regulations" [6-8].

It is healthcare units with effectively implemented and well-operated Quality Management Systems that give the patients such certainty.

An adverse event is understood as every single unintentional or unexpected event that could have caused or which caused damage to one or more patients using medical services.

These are the following adverse events that require monitoring and analysis: foreign object left in the operational area, inappropriate patients/place/operated side/operational procedure, catheter-related infection of vascular bed, body injury as a result of operational procedure, sepsis after operational procedure, pulmonary emboli or deep vein thrombosis after operational procedure, suicide in a hospital, wrong medication administration (wrong medication, patient, time, and way of administration), hospital collapses, overdue care provision, reoperation, unplanned, repeated hospitalisation, patient's unauthorised departure from the hospital, assault, rape, or murder, death resulting from delayed medical service, perinatal injuries and deaths [9-14].

When analysing the causes of adverse events, there are three questions that need to be asked:

1) What happened?

2) Why did it happen?

3) What can we do to prevent it from reoccurring?

4) We should not however, ask "who is to blame?" [15].

In the field of adverse events that have occurred, we may enumerate the ones that result from poor work organisation, lack of involvement, and professional burnout [16].

The main aim of the adverse events reporting system is the improvement of patient safety.

Such systems are called Reporting and Learning Systems (RLS). Reporting data about events matters only when such events constitute the subject of analysis, and when the medical personnel participating in the events receive feedback [10].

Safety is a key element in the quality of every healthcare system; however, a lack of error monitoring in medical events poses a threat to patients and personnel [17].

\section{Aim of the research}

The main objective of this work is to assess to what extent the quality of nursing care is conditioned by the unwanted events identification and to what degree it depends on the functioning of the quality management system.

In order to analyse the work's main objective some detailed issues were appointed:

- What is the most common kind of adverse event as regards the extent, conditioning, and influence on healthcare system functioning?

- What kind of supervision over adverse event identification should be introduced to make sure that the quality of medical services is in accordance with legal requirements?

- What actions should be taken to lower the fear of facing the consequences after adverse event reporting?

\section{Material and methods}

The research has been conducted, in which a group of 364 nurses participated. The research has been car- 
ried out among nurses working in hospitals that have and do not have Certificates of Quality Management System. The method that was used was a diagnostic survey. The research technique was a questionnaire.

In the research the following elements were used:

1. The Hospital Survey on Patient Culture prepared by the Agency for Healthcare Research and Quality. The survey is designed for healthcare workers and is used to assess personnel's knowledge about patient safety issues, medical errors, and adverse event reporting and to inspect opinions concerning the above-mentioned issues in their hospitals.

2. The author's own survey with questions concerning reporting undesirable events, and the safety and quality of the nursing care.

\section{Statistical analysis}

The rules of classic statistics were used in order to provide statistical analyses regarding the choice of materials and methods. The following elements were calculated: the compliance test $\chi^{2}$, Mann and Whitney $U$ Test, Kruskal and Wallis ANOVA Test, monodimensional analysis of variation and correlational methods.

The original method used in statistical analyses was the Hospital Survey Excel Tool 1.5 - Data Entry and Analysis Tool for the 2007 version of Microsoft Excel $^{\circledR}$ for the Hospital Survey - Your Hospitals Results.

\section{Results}

From the data analysis, it turns out that the quality system operates in the majority of examined healthcare system institutions (78\%). In only $16 \%$ there is a lack of any sort of quality system; however, in $6 \%$ of such institutions, the employees do not know of any quality system that works at all (Table 1).
The survey revealed a significant statistical difference $(p<0.001)$ between the awareness of whether quality systems function in the institutions and the presence of a Certificate of Quality Management System in the workplace. Statistically, when compared to other workers, there are more nurses among employees in institutions that have the certificate, who know that the quality system functions in their workplace. Almost all examined people (95\%) declared that they could define the terms of adverse event, only $5 \%$ of the surveyed said that they could not (Table 2).

The survey revealed a significant statistical difference $(p<0.001)$ between the declaration concerning the ability to define the term of adverse event by the surveyed people and the possession of the Certificate of Quality Management System marked by the healthcare institution. Statistically, when compared to other workers, there are more nurses among employees in institutions that do not have such a certificate, who do not know how to define the terms of an adverse event.

In the analyses, the nurses' opinions were taken into considerations; the ones regarding the link between early identification and prevention of adverse events in the context of patient safety. The majority of people found patients' safety good (61\%), and some found it very good (9\%); however, two people found the safety excellent (1\%). The rest (30\%) assessed the safety as negative (30\%), i.e. $26 \%$ described it as poor and $4 \%$ as bad (Table 3 ).

The survey revealed a significant statistical difference ( $p=0.004)$ between the surveyed people's assessment of patients' safety when it comes to the early discovery of an irregularity, and the age of the surveyed nurses. Statistically, when compared to other workers, there were more nurses up to 24 years old and there were fewer nurses at the age between 35 and 44 years, who assessed the patients' safety as excellent or very good. The vast majority of the surveyed people (71\%)

Table 1. Functioning of quality systems in institutions according to the surveyed people

\begin{tabular}{|lcccccc|}
\hline Answers & \multicolumn{5}{c|}{ Possession of a Certificate of Quality Management System } \\
\cline { 2 - 7 } & \multicolumn{2}{c}{ Certificate $(\boldsymbol{N}=\mathbf{2 6 4})$} & No certificate $(\boldsymbol{N}=100)$ & \multicolumn{2}{c|}{ In total $(\boldsymbol{N}=364)$} \\
\cline { 2 - 7 } & $n$ & $\%$ & $n$ & $\%$ & $n$ & $\%$ \\
Yes & 264 & 100 & 21 & 21.0 & 285 & 78.3 \\
No & 0 & - & 57 & 57.0 & 57 & 15.7 \\
I don't know & 0 & - & 22 & 22.0 & 22 & 6.0 \\
Answers in total & 264 & 100 & 100 & 100 & 364 & 100 \\
People in total & 264 & 72.5 & 100 & 27.5 & 364 & 100 \\
\hline
\end{tabular}

$\chi^{2}(n=364, d f=2)=266.37, p<0.001$ - as regards the quality certificate; Numbers lower than expected in the remaining group. Numbers higher than expected in the remaining group. $\chi^{2}(n=364, d f=2)=7.50, p=0.024$ - as regards the hospital ward type, $\chi^{2}(n=364, d f=6)=5.57, p=0.47$ n.s. - as regards nurses' age, $n$.s. - statistically irrelevant, $\chi^{2}(n=364, d f=4)=1.22, p=0.87$ n.s. - as regards work position, n.s. - statistically irrelevant, $\chi^{2}(n=364, d f=6)=18.40, p=0.005$ - as regards nurses' education; $\chi^{2}(n=364, d f=2)=8.68, p=0.013$ - as regards nurses' education level. 
Table 2. Declaration concerning the ability to define adverse events by the surveyed

\begin{tabular}{|lcccccc|}
\hline Answers & \multicolumn{3}{c|}{ The possession of the Certificate of Quality Management System } \\
\cline { 2 - 7 } & \multicolumn{2}{c}{ Certificate $(\boldsymbol{N}=\mathbf{2 6 0})$} & No certificate $(\boldsymbol{N}=\mathbf{9 5})$ & \multicolumn{2}{c|}{ In total $(\boldsymbol{N}=\mathbf{3 5 5})$} \\
\cline { 2 - 7 } & $\boldsymbol{n}$ & $\%$ & $n$ & $\%$ & $n$ & $\%$ \\
Yes & 253 & 97.3 & 83 & 87.4 & 336 & 94.6 \\
No & $\mathbf{7}$ & $\mathbf{2 . 7}$ & 12 & 12.6 & 19 & 5.4 \\
Answers in total & 260 & 100 & 95 & 100 & 355 & 100 \\
No answer & 4 & 1.5 & 5 & 5.0 & 9 & 2.5 \\
People in total & 264 & 72.5 & 100 & 27.5 & 364 & 100 \\
\hline
\end{tabular}

$\chi^{2}(n=355, d f=1)=13.57, p<0.001$ - as regards the quality certificate. Numbers lower than expected in the remaining group. Numbers higher than expected in the remaining group. $\chi^{2}(n=355, d f=1)=0.034, p=0.85$ n.s. - as regards the hospital ward type; $\chi^{2}(n=355, d f=3)=1.80, p=0.62$ n.s. - as regards nurses' age; $\chi^{2}(n=355, d f=2)=0.53, p=0.77$ n.s. - as regards work position, $\chi^{2}(n=355, d f=3)=1.68, p=0.64$ n.s. - as regards nurses' education.

Table 3. Early identification versus adverse events prevention regarding patient safety, according to the nurses

\begin{tabular}{|lcccccc|}
\hline Answers & \multicolumn{5}{c|}{ Possession of a Certificate of Quality Management System } \\
\cline { 2 - 7 } & \multicolumn{2}{c}{ Certificate $(N=261)$} & No certificate $(N=99)$ & \multicolumn{2}{c|}{ In total $(\boldsymbol{N}=360)$} \\
\cline { 2 - 7 } & $n$ & $\%$ & $n$ & $\%$ & $n$ & $\%$ \\
Excellent* & 2 & 0.8 & 0 & - & 2 & 0.6 \\
Very good* & 25 & 9.6 & 6 & 6.1 & 31 & 8.6 \\
Good & 164 & 62.8 & 56 & 56.6 & 220 & 61.1 \\
Poor & 60 & 23.0 & 33 & 33.3 & 93 & 25.8 \\
Bad & 10 & 3.8 & 4 & 4.0 & 14 & 3.9 \\
Answers in total & 261 & 100 & 99 & 100 & 360 & 100 \\
No answers & 3 & 1.1 & 1 & 1.0 & 4 & 1.1 \\
People in total & 264 & 72.5 & 100 & 27.5 & 364 & 10 \\
\hline
\end{tabular}

For the purpose of the statistical analysis the answers were combined. $\chi^{2}(n=360, d f=3)=4.88, p=0.18$ n.s. - as regards the quality certificate; $\chi^{2}(n=360, d f=3)=6.13, p=0.11$ n.s. as regards the hospital ward type; $\chi^{2}(n=360, d f=9)=24.06, p=0.004$ - as regards nurses' s age; $\chi^{2}(n=360, d f=6)=5.25, p=0.51$ n.s. - as regards work position; $\chi^{2}(n=360, d f=9)=15.82, p=0.07$ n.s. - as regards nurses 'education.

answered that in their healthcare institutions such adverse events are discussed and analysed in detail by a special team created to prevent recurrence of such adverse events. Seventeen percent of those surveyed answered that such events are discussed and analysed sporadically and/or only in the face of an upcoming external audit. In every eighth case (12\%) such events were not discussed (Table 4).

The survey revealed a significant statistical difference ( $p=0.049$ ) between the kind of actions taken to prevent adverse events from recurring and the presence of a Certificate of Quality Management System in the workplace. Statistically, when compared to other workers, there are more people among nurses working in institutions that do not have the certificate, who answered that in their workplace the adverse events are not discussed.
In the analyses, the areas that were taken into consideration were the ones in which the discrepancies are most often identified. The inconsistencies most frequently identified by the nurses were linked with organisation and administration (35\%), medical equipment (24\%), hospital infections (23\%), medication administration (22\%), doctors' activities (20\%), and nurses' activities (19\%). Although the least identified inconsistency was linked to blood and blood-related specimens, such incidents were reported by one in ten persons (10\%) (Table 5).

The survey revealed a significant statistical difference ( $p=0.042$ ) between how the surveyed people identified the inconsistencies linked to blood and blood-related specimens and the possession of a Certificate of Quality Management System by the healthcare institution. Statistically, there were fewer people 
Table 4. Actions taken to prevent adverse events recurrence in healthcare institutions, according to the surveyed

\begin{tabular}{|c|c|c|c|c|c|c|}
\hline \multirow[t]{3}{*}{ Answers } & \multicolumn{6}{|c|}{ The possession of the Certificate of Quality Management System } \\
\hline & \multicolumn{2}{|c|}{ Certificate $(N=247)$} & \multicolumn{2}{|c|}{ No certificate $(N=97)$} & \multicolumn{2}{|c|}{ In total $(N=344)$} \\
\hline & $n$ & $\%$ & $n$ & $\%$ & $n$ & $\%$ \\
\hline $\begin{array}{l}\text { The events are discussed } \\
\text { and analysed in detail by the team } \\
\text { for adverse events appointed } \\
\text { in the healthcare institution }\end{array}$ & 183 & 74.1 & 60 & 61.9 & 243 & 70.6 \\
\hline The adverse events are not discussed & 25 & 10.1 & 18 & 18.6 & 43 & 12.5 \\
\hline $\begin{array}{l}\text { The events are discussed and } \\
\text { analysed sporadically, in the case } \\
\text { of an external audit coming to the } \\
\text { healthcare institution }\end{array}$ & 39 & 15.8 & 19 & 19.6 & 58 & 16.9 \\
\hline Answers in total & 247 & 100 & 97 & 100 & 344 & 100 \\
\hline No answers & 17 & 6.4 & 3 & 3.0 & 20 & 5.5 \\
\hline People in total & 264 & 72.5 & 100 & 27.5 & 364 & 100 \\
\hline
\end{tabular}

$\chi^{2}(n=344, d f=2)=6.04, p=0.049$ - as regards the quality certificate; Numbers higher than expected in the remaining group; $\chi^{2}(n=344, d f=2)=3.88, p=0.14$ n.s. - as regards the hospital ward type, $\chi^{2}(n=344, d f=6)=1.49, p=0.96$ n.s. - as regards nurses' age; $\chi^{2}(n=344, d f=4)=4.75, p=0.31$ n.s. - as regards work position; $\chi^{2}(n=344, d f=6)=11.89, p=0.06$ n.s. - as regards nurses' education.

Table 5. The importance levels for the chosen areas of identifying adverse events in the system of established variables

\begin{tabular}{|lccccc|}
\hline Chosen areas of adverse events & \multicolumn{5}{c|}{ As regards independent variables } \\
\cline { 2 - 6 } & $\begin{array}{c}\text { Quality } \\
\text { certificate }\end{array}$ & $\begin{array}{c}\text { Hospital } \\
\text { ward type }\end{array}$ & $\begin{array}{c}\text { Nurses' } \\
\text { age }\end{array}$ & $\begin{array}{c}\text { Work } \\
\text { position }\end{array}$ & $\begin{array}{c}\text { Nurses' } \\
\text { education } \\
\text { (level) }\end{array}$ \\
Blood and blood-related specimen inconsistencies & 0.042 & 0.61 & 0.85 & 0.64 & 0.038 \\
Medication administration inconsistencies & 0.72 & $<0.001$ & 0.034 & 0.62 & 0.09 \\
Medical equipment inconsistencies & 0.18 & 0.29 & 0.69 & 0.31 & $0.08(0.044)$ \\
Hospital infections inconsistencies & 0.86 & 0.74 & 0.15 & 0.44 & 0.10 \\
Nurses' activities inconsistencies & 0.14 & 0.26 & 0.14 & 0.10 & 0.89 \\
Doctors' activities inconsistencies & 0.015 & 0.66 & 0.19 & 0.54 & 0.48 \\
Organization and administration inconsistencies & 0.038 & 0.17 & 0.78 & 0.46 & 0.53 \\
\hline
\end{tabular}

among nurses working in institutions that did not have the certificate, who identified the inconsistencies linked to blood and blood-related specimens.

In the analyses, the subjective evaluation concerning the appearance of adverse events was taken into consideration. The 1-6 scale was used, where 1 constitutes the lowest value and 6 constitutes the highest one. Nurses evaluated the appearance of adverse events as 3 for the following reasons: the patient (38\%), the workplace (36\%), communication (30\%), equipment (28\%), and service provision (30\%).

In the situations of adverse incidents that happened, the surveyed nurses took some amending and preventive actions: the majority (66\%) reported the patients' injury, giving the date, extent, and kind of injury in the patients' medical history. Only $6 \%$ of the surveyed nurses answered that they did not report the patients' injury in their medical history, and as many as $28 \%$ of the surveyed did not know if any amending or preventive actions were taken to report the injury in the patient's medical history.

It was noted that $64 \%$ of the nurses had been asked to perform doctor's oral or phone orders in a situation that did not threaten the patient's life. To the most common activities inconsistent with their competences but still performed by the nurses, the following ones were included: performing nursing activities ordered by the doctor that were written in the card of orders without authorisation (30\%), giving blood and blood-related specimens without required qualifications (25\%), and introducing the doctor's orders into the card of orders $(24 \%)$. 
Table 6. Patient safety evaluation in the context of early discovery of inconsistencies and adverse events prevention

\begin{tabular}{|lcccccc|}
\hline Patients' safety evaluation & \multicolumn{3}{c|}{ Possession of a Certificate of Quality Management System } \\
\cline { 2 - 7 } & Certificate $(N=261)$ & No certificate $(N=100)$ & In total $(\boldsymbol{N}=361)$ \\
\cline { 2 - 7 } & $n$ & $\%$ & $n$ & $\%$ & $n$ & $\%$ \\
Excellent & 2 & 0.8 & 1 & 1.0 & 3 & 0.8 \\
Very good & 34 & 13.0 & 5 & 5.0 & 39 & 10.8 \\
Good & 170 & 65.1 & 62 & 62.0 & 232 & 64.3 \\
Poor & 46 & 17.6 & 28 & 28.0 & 74 & 20.5 \\
Bad & 9 & 3.4 & 4 & 4.0 & 13 & 3.6 \\
Answers in total & 261 & 100 & 100 & 100 & 361 & 100 \\
No answer & 3 & 1.1 & - & - & 3 & 0.8 \\
People in total & 264 & 72.5 & 100 & 27.5 & 364 & 100 \\
\hline
\end{tabular}

$\chi^{2}(n=361, d f=4)=8.33, p=0.08$ n.s. - as regards the quality certificate; $\chi^{2}(n=361, d f=4)=8.79, p=0.07 n$.s. - as regards the hospital ward type; $\chi^{2}(n=361, d f=12)=34.63, p<0.001$ - as regards nurses' age; $\chi^{2}(n=361, d f=8)=8.14, p=0.42$ n.s. - as regards work position; $\chi^{2}(n=361, d f=12)=23.85, p=0.021$ - as regards nurses' education; $\chi^{2}(n=361, d f=4)=7.72, p=0.10$ n.s. - as regards nurses' education level.

Unfortunately, most of the nurses (55\%) were not willing to inform their supervisors about the adverse incidents that happened, and as many as $16 \%$ of them did not report such events, because they were afraid of disciplinary sanctions. Only $17 \%$ of the nurses reported such events, because they believed that this is in accordance with their professional ethics; however, $13 \%$ of them were aware of how important the information about adverse incidents is in the process of the patient's treatment.

Over 55\% of the nurses attributed the lack of initiative concerning adverse incident reporting to the policy of their work place. Such reporting does not lead to the perception of the problem occurrence but to the punishment of the reporting person.

The majority of the nurses (64\%) positively evaluated patient safety in the context of an early discovery of some irregularity and its prevention. The safety was evaluated as very good or excellent only by $12 \%$; however, as many as $24 \%$ of the surveyed evaluated it as poor or bad (Table 6).

The survey revealed a significant statistical difference $(p<0.001)$ between the nurses' age and how they evaluated the early discovery of inconsistencies and adverse events prevention. Statistically, there were more nurses in the age of up to 24 years, when compared to the other nurses who evaluated patient safety as good and/or excellent in the context of early discovery of inconsistencies.

The survey revealed a significant statistical difference ( $p=0.021)$ between the patient safety evaluation in the context of an early discovery of inconsistency and adverse events prevention and the nurses' education. Statistically, there were more nurses with BA de- grees, who evaluated the patients' safety as very good in the context of early discovery of an inconsistency.

When it comes to completing reports on adverse incidents that had happened, the surveyed nurses $(65 \%)$ answered that within the last year they had not completed or handed in any report on the errors and inconsistencies, one in every fourth nurse (23\%) had completed 1-2 reports, and 9\% of the nurses had completed 3-5 reports. The rest of the surveyed (3\%) completed and delivered more than 5 reports on errors and inconsistencies (Table 7).

The survey revealed a significant statistical difference ( $p=0.003)$ between the number of reports on errors and inconsistencies completed and delivered by the surveyed nurses within the last 12 months and the possession of Certificate of Quality Management System by the healthcare institution. Statistically, there were fewer people among nurses working in the institutions that did not have a certificate, who answered that within the last 12 months they had completed and delivered 1-2 reports on errors and inconsistencies.

Despite the low percentage of identifying, reporting, and analysing adverse events, especially completing the documentation in force by all the nurses, as documented in statistical data (Hospital Survey Excel Tool 1.5, Azam), where $65 \%$ did not report any adverse events, $23 \%$ reported $1-2$ events, 9\% reported 3-5 events, $2 \%$ reported $6-10$ events, and only $1 \%$ reported 11-20 events, nursing care was evaluated positively (Figure 1).

The research (Hospital Survey Excel Tool) showed that nursing care was in $2 \%$ of cases excellent, $46 \%$ very good, $43 \%$ acceptable, $7 \%$ poor, and only $1 \%$ constituted the lack of such care or its unacceptable form (Figure 2). 
Table 7. The number of reports on errors and inconsistencies that were completed and filed by the nurses within the last 12 months

\begin{tabular}{|c|c|c|c|c|c|c|}
\hline \multirow[t]{3}{*}{ Reports number } & \multicolumn{6}{|c|}{ The possession of the Certificate of Quality Management System } \\
\hline & \multicolumn{2}{|c|}{ Certificate $(N=263)$} & \multicolumn{2}{|c|}{ No certificate $(N=97)$} & \multicolumn{2}{|c|}{ In total $(N=360)$} \\
\hline & $n$ & $\%$ & $n$ & $\%$ & $n$ & $\%$ \\
\hline No reports & 163 & 62.0 & 72 & 74.2 & 235 & 65.3 \\
\hline $1-2$ reports & 73 & 27.8 & 9 & 9.3 & 82 & 22.8 \\
\hline $3-5$ reports & 21 & 8.0 & 13 & 13.4 & 34 & 9.4 \\
\hline 6-10 reports* & 3 & 1.1 & 3 & 3.1 & 6 & 1.7 \\
\hline 11-20 reports* & 3 & 1.1 & 0 & - & 3 & 0.8 \\
\hline 21 or more reports & - & - & - & - & - & - \\
\hline Answers in total & 263 & 100 & 97 & 100 & 360 & 100 \\
\hline No answer & 1 & 0.4 & 3 & 3.0 & 4 & 1.1 \\
\hline People in total & 264 & 72.5 & 100 & 27.5 & 364 & 100 \\
\hline
\end{tabular}

${ }^{*}$ For the purpose of the statistical analysis the answers were combined; $\chi^{2}(n=360, d f=3)=14.64, p=0.002$ - as regards the quality certificate; Numbers lower than expected in the remaining group. $\chi^{2}(n=360, d f=3)=9.07, p=0.028$ - as regards the hospital ward type; $\chi^{2}(n=360, d f=9)=4.97, p=0.84$ n.s. - as regards nurses' age; $\chi^{2}(n=360, d f=6)=7.85, p=0.25$ n.s. - as regards work position; $\chi^{2}(n=360, d f=9)=6.14, p=0.72$ n.s. - as regards nurses' education.

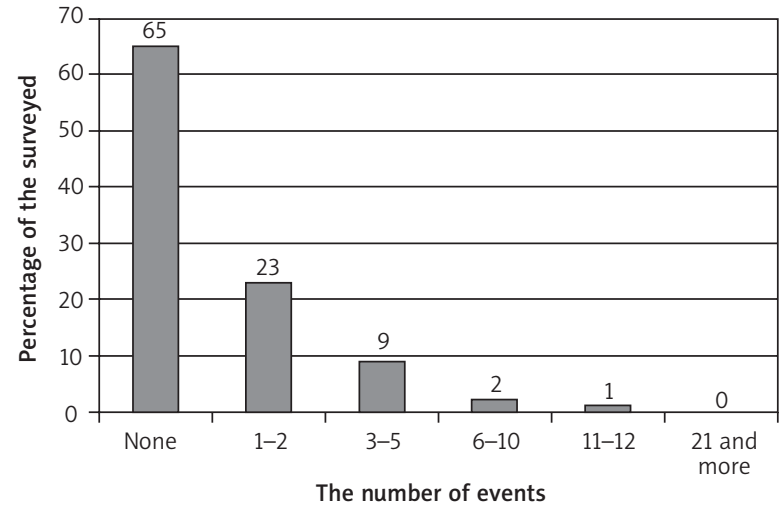

Figure 1. Number of events according to Hospital Survey Patient Safety

\section{Discussion}

The main aim of the carried out research was to evaluate to what extent the quality of nursing care is conditioned by adverse events identification and by the functioning of the quality management system.

The nurses enumerated some of the factors that contribute to adverse incidents occurrence, while they were performing their nursing activities, namely, reduced nursing personnel when compared to the number of performed tasks, inappropriate relations among employees, unclear task division, qualifications, responsibilities, working conditions, time pressure, unsatisfying salary, and unsuccessful cooperation with doctors. They also mentioned that it is

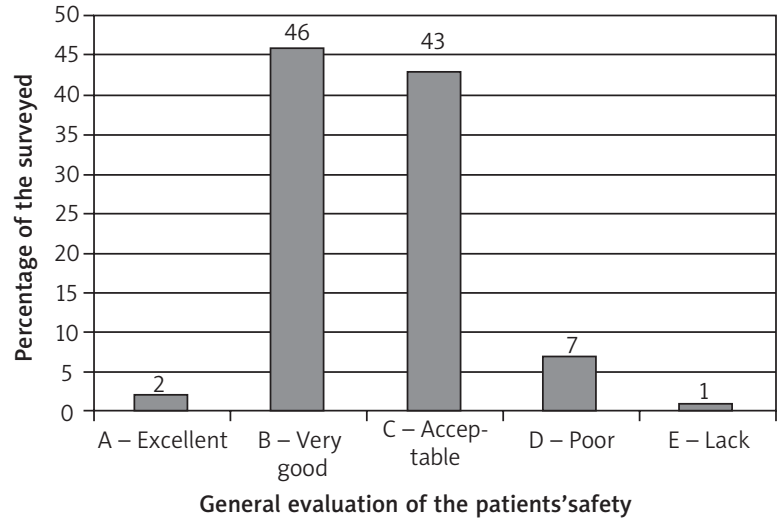

Figure 2. General evaluation of the patients' safety according to Hospital Survey Patient Safety

common to perform doctors' orders given orally or over the phone. According to the surveyed nurses, all the above-mentioned situations contributed to adverse events occurrence while they were performing nursing activities when treating a patient [18-23].

Identification of adverse events in nursing leads to many doubts and misunderstandings. Collecting information about inconsistencies causes mistrust and a feeling of threat.

The basic tool for identification of adverse events in quality management systems is adverse events reports [24].

The fear of consequences is the reason for the small amount of completed reports on adverse events. The research results can be confirmed in Kutryba's 
and Czarnecka's research, where the nurses were also afraid to file a report for fear of it being used against them [25-29].

As the most commonly given cause of their fear to report adverse events, the Polish nurses mentioned the fear of disciplinary sanctions. In order to create safety, the reporting system should eliminate the feeling of guilt and fear of facing consequences for unintentional actions [30].

Although the nurses were afraid of the consequences in case of reporting inconsistencies, the majority of them were willing to admit to the occurred situation.

To reduce these fears while reporting adverse events, the key task is to provide information about the importance of such incident reporting, and to introduce, implement, and skilfully apply the tools and methods that will rationally protect nurses and contribute to building a safe working environment [29].

It can be predicted that in the $21^{\text {st }}$ century we will face growth in the number of people with many health issues, which will bring social, economic, and political consequences and will have an influence on the kind of medical services provided. It is important to implement a unified system of adverse events reporting, even though we can observe a need to increase the financial means in healthcare in other areas. Such a solution will, eventually, lower the cost of healthcare, guarantee high quality of provided serviced, increase the feeling of safety, and improve the quality of people's lives.

\section{Conclusions}

It was observed that adverse events in nursing in the field of performing procedural and care activities constitute a problem and may become a threat to the quality of patient care. In hospitals that possess quality management systems, the identification of adverse incidents by nurses is in accordance with procedures, which has a significant influence on the standardisation of nurses' proceedings. The survey revealed numerous cases of not reporting adverse events by the nurses, which was conditioned by the fear of disciplinary sanctions, which is why it is crucial to create safety in healthcare institutions. It is necessary to introduce legal regulations regarding the tool used to report adverse events in the country in accordance with European Union Regulations. It is crucial to create and introduce educational programs for medical professions, concerning adverse events prevention. As a result, it will ensure patient safety and will guarantee high quality of medical services.

\section{Conflict of interest}

The authors declare no conflict of interest.

\section{References}

1. Krukowski J. Błędy i zaniedbania w medycynie. VII Ogólnopolska Konferencja "Jakość w Opiece Zdrowotnej”. CMJ, Kraków 22-24 April 2000.

2. Gajewski P, Krajewski R. Bezpieczny pacjent - bezpieczny lekarz - bezpieczny szpital. Med Prakt 2011; 1: 191-24.

3. Gruca-Wójtowicz P. Identyfikacja zdarzeń niepożądanych jako element systemu zarządzania jakością w ochronie zdrowia. In: Kierunki doskonalenia usług w ochronie zdrowia. Lisiecka-Biełanowicz M, Samoliński B, Warczyński P. Ministerstwo Zdrowia, Warsaw 2010; 96-103.

4. Gruca-Wójtowicz P, Mika M. Niezgodności w usługach pielęgniarskich. Problemy Jakości 2011; 5: 27-31.

5. Głowacka MD, Staszewski R. Pojęcie jakości. Od teorii do praktyki. In: Zarządzanie zakładem opieki zdrowotnej. Wybrane konteksty teoretyczno-praktyczne. Głowacka MD (red.). Termedia, Poznań 2004.

6. Ustawa $z$ dnia 6 listopada 2008 roku o prawach pacjenta i Rzeczniku Praw Pacjenta (Dz. U. 2009 Nr 52, poz. 417).

7. Krukowski J. Błędy i zaniedbania w medycynie. VII Ogólnopolska Konferencja „Jakość w Opiece Zdrowotnej”. CMJ, Kraków 22-24 kwietnia 2000; 25-30.

8. Program Akredytacji Szpitali. Zestaw Standardów Akredytacyjnych. CMJ. Kraków 2009; 105-112.

9. Cranovsky RS, Krajewski R. Zdarzenia niepożądane w lecznictwie i błędy medyczne. Medycyna Praktyczna 2011; 2: 127-132.

10. Śpiewankiewicz J, Rogala-Pawelczyk G. Błędy postępowania pielęgniarskiego - przyczyny, konsekwencje, prewencja. VII Ogólnopolska Konferencja - Jakość w Opiece Zdrowotnej. CMJ, Kraków 2002.

11. Kutryba B, Kutaj-Wasikowska H. Bezpieczny pacjent, bezpieczny szpital. Menadżer Zdrowia 2003; 3: 24-6.

12. Kutryba B. Bezpieczeństwo pacjenta - rozwiązania europejskie. Konferencja: Bezpieczny pacjent - bezpieczny szpital - bezpieczny lekarz. Warszawa 2011.

13. Anhoej J, Skjot P. Analiza zdarzeń niepożądanych w szpitalu - praktyczne wskazówki dla Zespołu Jakości. XV Ogólnopolska Konferencja - Jakość w Opiece Zdrowotnej. CMJ, Kraków 2011.

14. Moghri J, Arab M, Akbari Saari A, et al. The Psychometric Properties of the farsi version of Hospital Survey on Patient safety Culture in Iran's Hospitals. Iranian J Publ Health 2012; 41: 80-6.

15. Ferner R. Medical error the plane truth. BMJ 2008; 337: 411.

16. Gajewski P, Krajewski R. Bezpieczny pacjent - bezpieczny lekarz - program dla środowiska medycznego. Med Prakt 2011; 1: 119-26.

17. Gruca-Wójtowicz P, Mika M. Niezgodności w usługach pielęgniarskich. Problemy Jakości 2011; 5: 27-31.

18. Gaweł G, Pater B, Potok H, et al. Świadomość odpowiedzialności zawodowej wśród pielęgniarek. Problemy Pielęgniarstwa 2010; 18: 105-110, 96-103.

19. Kwiecień K, Wujtewicz M, Mędrzycka-Dąbrowska W. Selected methods of measuring workload among intensive care nursing staff. Int J Occup Med Environ Health 2012; 25: 209-17.

20. Perek M, Kózka M, Twarduś K. Trudne sytuacje w pracy pielęgniarek pediatrycznych i sposoby radzenia sobie z nimi. Problemy Pielęgniarstwa 2007; 15: 223-8. 
21. Kennedy BR. Stress and burnount of nursing staff working with geriatric clients in long-term care. J Nursing Scholarship 2005; 37: 381.

22. Shaver K, Lacey L. Job and career satisfaction among staff nurses. JONA 2003; 33: 166-72.

23. Kwak C, Chung BY, Eun-Jung C. Relationship of job satisfaction with perceived organizational support and quality of care among South Korean nurses: a questionnaire survey. Int Nurses Study 2010; 17: 36-41.

24. Vaz K, Mcgrowder D, Crawford T, et al. Prevalance of injuries and reporting of accidents among health care workers at the University Hospital of the West Indies. Int J Occup Med Environ Health 2010; 23: 133-43.

25. Kutryba B. Dokumenty Centrum Monitorowania Jakości w Ochronie Zdrowia. Kraków. Polish presentation Safe Patient, Safe Hospital. A Prelude to culture of safety in Polish hospitals - April $2006 \mathrm{r}$.

26. Czarnecka J, Sulewska M, Wieczorek A, et al. Ocena bezpieczeństwa pacjenta na podstawie wiedzy pielęgniarek. Problemy Pielegniarstwa 2010; 18: 101-4.

27. Badir A, Herdman EA. Critical care nurses percepitions of patient safety in Turkey. J Nurs Care Qual 2008; 23: 375-8.

28. Donaldson L. An organisation with a memory. Clin Med 2002; 2: 456-7.

29. Nowak-Starz G, Kozak B, Zdziebło K. Wpływ stresu związanego z pracą zawodową na występowanie zespołu wypalenia zawodowego u pielęgniarek pracujących w oddziałach zabiegowych i zachowawczych. Studia Medyczne 2013; 29: 15-21.

30. Program RN4CAST. 100-lecie pielęgniarstwa w Polsce. Teoria i praktyka pielęgniarstwa XXI wieku. Międzynarodowa Konferencja Naukowa, Kraków 2011.

\section{Address for correspondence:}

Maria Mika MD

Department of Nursing, The Institute of Health Science,

State Higher Vocational School, Tarnow, Poland

ul. Mickiewicza 8, 33-100 Tarnow, Poland

Phone: +48 693235793

E-mail: mikamaria@wp.pl 